\title{
KERAGAMAN DAN HERITABILITAS KARAKTER VEGETATIF CABAI MERAH (Capsicum annum L.) VARIETAS LARIS GENERASI M2 HASIL IRADIASI SINAR GAMMA
}

\section{VARIABILITY AND HERITABILITY OF VEGETATIVE CHARACTERS OF RED CHILI (Capsicum annum L.) LARIS VARIETY OF M2 GENERATION AS THE RESULTS OF GAMMA RAY IRRADIATION}

\author{
Erik Suwandana*, Rugayah, Ardian, Nyimas Sa'diyah \\ Jurusan Agroteknologi Fakultas Pertanian Universitas Lampung \\ Jalan Prof. Dr. soemantri Brojonegoro No.1 Bandar Lampung 35145 \\ *Email:eriksw22@gmail.com
}

\begin{abstract}
The decreasing productivity of national chilies can be solved by the using of superior varieties assembling starting with the variability. One way to increase the variability of artificial mutations by using of gamma ray irradiation on chili seeds. This research aims to determine (1) the magnitude of the variability of vegetative characters of red chili plants Laris variety $M 2$ generation results from gamma irradiation and (2) the magnitude of the heritability value of vegetative characters of red chili plants Laris variety M2 generation from gamma ray irradiation. Gamma ray irradiation was carried out at the Center for Research and Development of Isotope and Radiation Technology, Pasar Jumat, Jakarta on June 15, 2016, while planting M2 seeds was carried out in the Integrated Field, Faculty of Agriculture, University of Lampung in September 2017 to March 2018. This research use a single plant methode. The results showed that observations of germination rate and percentage of normal seedlings in M2 generation were better than $M 0$, whereas observations of the percentage of germination and simultaneity of germination of M2 generation were lower than M0. The wide variability of phenotypes was found in the characters of seedling height and plant dicotomus, while the variability of genotypes of all characters showed narrow criteria. The magnitude of the high heritability estimated value is shown in the character of the number of primary branches and stem diameter, for the parameters of seedling height, plant dicotomus, and length of the primary branch showed the low criteria.
\end{abstract}

Keywords: Gamma ray irradiation, heritabilility, red chili, variability

\begin{abstract}
ABSTRAK
Produktivitas cabai nasional yang terus menurun dapat diatasi dengan penggunaan perakitan varietas unggul diawali dengan keragaman salah satu cara meningkatkan keragaman yaitu dengan mutasi buatan dengan cara iradiasi sinar gamma pada benih cabai. Penelitian ini bertujuan untuk mengetahui (1) besaran keragaman karakter vegetatiftanaman cabai merah varietas Laris generasi M2 hasil iradiasi sinar gamma dan (2) besaran nilai heritabilitas karakter vegetatif tanaman cabai merah varietas Laris generasi M2 hasil iradiasi sinar gamma. Iradiasi sinar
\end{abstract}


gamma dilakukan di Pusat Penelitian dan Pengembangan Teknologi Isotop dan Radiasi, Pasar Jumat, Jakarta pada tanggal 15 Juni 2016, sedangkan penanaman benih M2 dilakukan di Lapangan Terpadu, Fakultas Pertanian, Universitas Lampung pada bulan September 2017 sampai dengan bulan Maret 2018. Penelitian ini menggunakan metode single plant. Hasil penelitian menunjukkan bahwa pengamatan kecepatan perkecambahan dan presentase bibit normal pada generasi M2 lebih baik dibandingkan M0, sedangkan pengamatan presentase perkecambahan dan keserempakan perkecambahan generasi M2 lebih rendah dibandingkan dengan M0. Keragaman fenotipe yang luas terdapat pada karakter tinggi bibit dan tinggi dikotomus tanaman saat berbunga, sedangkan keragaman genotipe semua karakter menunjukkan kriteria yang sempit. Besaran nilai duga heritabilitas yang tinggi ditunjukkan pada karakter jumlah cabang primer dan diameter batang, untuk parameter tinggi bibit, tinggi tanaman saat berbunga, dan panjang cabang primer menunjukkan kriteria yang rendah.

Kata kunci: Cabai merah, heritabilitas, iradiasi sinar gamma, keragaman.

\section{PENDAHULUAN}

Cabai merah menjadi tanaman sayuran yang penting karena memiliki nilai ekonomis yang tinggi. Namun konsumsi buah cabai baik untuk kebutuhan industri maupun kebutuhan rumah tangga dari tahun ke tahun semakin meningkat. Produktivitas cabai merah mengalami penurunan pada tahun 2015 dari 8,65 ton ha-1 menjadi 8,47 ton ha-1 pada tahun 2016 (Badan Pusat Statistik, 2017). Hal ini menunjukkan bahwa produktivitas cabai nasional masih perlu ditingkatkan. Untuk meningkatkan produksi tanaman cabai memerlukan budidaya yang baik, salah satunya yaitu dengan penggunaan kultivar unggul yang memiliki daya hasil tinggi. Namun ketersediaan kultivar unggul cabai merah di masyarakat masih terbatas. Maka diperlukan penelitian untuk membuat kultivar yang unggul. Salah satu cara perakitan kultivar unggul yaitu dengan kegiatan pemuliaan tanaman.

Dalam kegiatan pemuliaan tanaman salah satu faktor yang berpengaruh yaitu keragaman genetik. Keragaman genetik merupakan parameter yang perlu dicermati dalam memilih suatu populasi yang akan diseleksi. Keberhasilan pemuliaan tanaman sangat ditentukan oleh besar kecilnya keragaman dan tinggi rendahnya rata-rata populasi tanaman tersebut. Salah satu cara untuk memperoleh keragaman dari suatu tanaman dapat dilakukan dengan cara mutasi. Mutasi adalah perubahan struktural atau komposisi genom suatu jasad yang dapat terjadi karena faktor luar (mutagen) atau karena kesalahan replikasi. Mutagen yang biasanya digunakan adalah radiasi sinar gamma karena iradiasi sinar gamma memiliki daya tembus yang lebih dalam pada target sel dari material tanaman yang diinduksi. Perbaikan karakter melalui program pemuliaan tanaman membutuhkan banyak informasi antara lain tentang keragaman genetik dan heritabilitas.

Nilai duga heritabilitas suatu karakter perlu diketahui untuk menentukan apakah karakter tersebut lebih banyak dipengaruhi oleh faktor genetik atau lingkungan(Yunianti dkk., 2010). Nilai heritabilitas yang tinggi berarti faktor keragaman genetik berperan penting dalam penampilan fenotipe pada tanaman (Ishak, 2012). Pada penelitian Lestari dkk. (2015) menyatakan tinggi tanaman, jumlah polong isi, jumlah 
biji bernas dan bobot bulir tanaman pada galur mutan lebih tinggi dibanding induknya atau kontrol. Purba dkk. (2013) menyatakan hasil pengamatan tanaman kedelai untuk parameter tinggi tanaman memiliki keragaman fenotipe yang luas. Syukur dkk. (2011) menyatakan pada pengamatan tanaman cabai karakter tinggi tanaman dan diameter batang memiliki keragaman genotipe yang sempit.

Tujuan penelitian ini adalah mengetahui besaran keragaman karakter vegetatif tanaman cabai merah varietas Laris generasi M2 hasil iradiasi sinar gamma dan mengetahui besaran nilai heritabilitas karakter vegetatif tanaman cabai merah varietas Laris generasi M2 hasil iradiasi sinar gamma.

\section{BAHAN DAN METODE}

Penelitian ini dilakukan di Lapangan Terpadu Fakultas Pertanian, Universitas Lampung dan Laboratorium Benih dan Pemuliaan Tanaman Fakultas Pertanian, Universitas Lampung, pada bulan September 2017 sampai dengan Bulan Maret 2018. Bahan yang digunakan yaitu benih cabai mutan M2 varietas Laris yang telah diberi perlakukan iradiasi sinar gamma dengan dosis 400 Gy dan benih cabai varietas Laris tanpa iradiasi sinar gamma (M0). Penelitian ini menggunakan metode single plant.

Benih yang ditanam sebanyak 144 benih M2 dan 48 benih M0 pada petak percobaan berukuran $5,3 \times 12 \mathrm{~m}$ dengan jarak tanam $50 \times 70 \mathrm{~cm}$. Penyemaian dilakukan dengan menggunakan media tanah yang telah dicampur kompos dengan perbandingan 1:1 dan dimasukkan ke dalam plastik bening berukuran sedang yang telah diberi lubang. Pindah tanam dilakukan dengan cara ditugal pada saat bibit cabai yang disemai telah berumur 4 minggu atau telah memiliki 2-3 pasang daun sejati, pada masingmasing lubang tugalan ditambahkan kompos sebanyak 150 gram (4,5 tonha-1). Pemupukan dilakukan dengan pupuk urea sebanyak 6,6 g/tanaman (200 kgha-1) dan $\mathrm{KCl}$ sebanyak 3,3 g/tanaman (100 kgha-1) saat tanaman berumur 21,42, dan 63 hari, serta pupuk TSP sebanyak 2,9 g/tanaman (90 kgha-1) saat tanaman berumur 21 hst. Pengendalian OPT dilakukan pada saat terjadi serangan dari OPT, pengendalian dapat dilakukan secara manual atau kimiawi sesuai dengan jenis OPT yang menyerang.

Variabel pengamatan pada penelitian ini adalah presentase perkecambahan, kecepatan perkecambahan, tinggi bibit, presentase bibit normal, keserempakkan berkecambah, tinggi dikotomus tanaman saat berbunga, panjang cabang primer, jumlah cabang primer dan diameter batang pada posisi $1 \mathrm{~cm}$ di bawah cabang. Data pengamatan dianalisis dengan melakukan pendugaan nilai heritabilitas arti luas dengan membandingkan nilai ragam genotipe dan nilai ragam fenotipe $\sigma_{f}^{2}$ ditentukan dengan rumus :

$$
\sigma_{f}^{2}=\frac{\sum_{i=l}^{n}(X i-\mu)^{2}}{N}
$$

Keterangan:

$\mathrm{Xi}=$ nilai pengamatan $\mathrm{ke}-\mathrm{i}$;

$\mu=$ nilai tengah populasi;

$\mathrm{N}=$ jumlah tanaman yang diamati 
Ragam fenotipe adalah kombinasi dari ragam genetik dan ragam lingkungan dihitung dengan rumus

$$
\sigma_{f}^{2}=\sigma_{g}^{2}+\sigma_{e}^{2}
$$

Pada penelitian ini M0 yang digunakan tanpa perlakuan, sehingga M0 dianggap homogen. Karena M0 homogen maka $\sigma_{g}^{2} \mathrm{M} 0=0$, maka:

$$
\sigma_{f}^{2} M 0=\sigma_{e}^{2} M 0
$$

Karena pada penelitian ini M2 ditanam di lingkungan yang sama dengan M0, maka

$$
\sigma_{e}^{2}{ }_{e}=\sigma_{e}^{2}{ }_{e}
$$

Keterangan :

$\sigma_{g}^{2}=$ ragam genotipe;

$\sigma_{f}^{2}=$ ragam fenotipe;

$\sigma_{e}^{2}=$ ragam lingkungan.

Suatu karakter populasi tanaman memililki keragaman genetik dan keragaman fenotipe yang luas apabila keragaman genetik dan keragaman fenotipe lebih besar dua kali simpangan bakunya.

$$
\sqrt{\sigma^{2}}=\sqrt{\frac{\sum_{i=l}^{n}(X i-\mu)^{2}}{N}}
$$

Keterangan :

$\sqrt{\sigma^{2}}=$ simpangan baku;

$\mathrm{Xi}=$ nilai pengamatan $\mathrm{ke}-1$;

$\mu=$ nilai tengah populasi;

$\mathrm{N}=$ jumlah tanaman yang diamati

Heritabilitas dalam arti luas merupakan perbandingan antara varians genetik dan varians fenotipe, sehingga dugaan heritabilitas dapat dirumuskan sebagai berikut.
Keterangan:

$$
\mathrm{H}=\frac{\sigma_{\mathrm{g}}^{2}}{\sigma_{f}^{2}}
$$

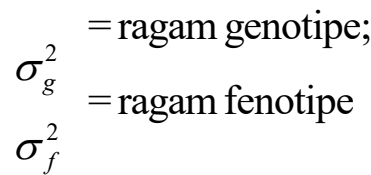

Nilai heritabilitas berkisar antara $0 \mathrm{H} 1$. Kriteria heritabilitas tersebut ialah: Heritabilitas tinggi apabila $\mathrm{H}>0,5$; Heritabilitas sedang apabila $0,2 \quad \mathrm{H}$ 0,5 ; Heritabilitas rendah apabila $\mathrm{H}<0,2$ (Syukur dkk., 2011)

\section{HASIL DAN PEMBAHASAN}

Berdasarkan hasil pengamatan menunjukkan bahwa presentase perkecambahan dan keserempakkan perkecambahan tanaman cabai varietas Laris hasil iradiasi sinar gamma dengan dosis 400 Gy generasi M2 lebih rendah dibandingkan dengan generasi M0 (Gambar 1 dan 4). Adanya penurunan rata-rata pada karakter tersebut diduga sebagai wujud ekspresi negatif dari gen-gen yang telah bermutasi. Pada penelitian Pinasthika dkk. (2018) hasil presentase berkecambah menunjukkan bahwa benih kedelai varietas Detam 3 Prida hasil mutasi iradiasi sinar gamma pada generasi M2 memiliki presentase perkecambahan yang lebih rendah apabila dibandingkan dengan M0. Nurrachmamila (2017) hasil pengamatan keserempakan tumbuh benih padi hasil iradiasi sinar gamma dengan dosis 400 gy terjadi penurunan sebesar $96,67 \%$

Pada hasil pengamatan parameter kecepatan perkecambahan dan presentase bibit normal tanaman generasi M2 lebih tinggi dibandingkan dengan tanaman 


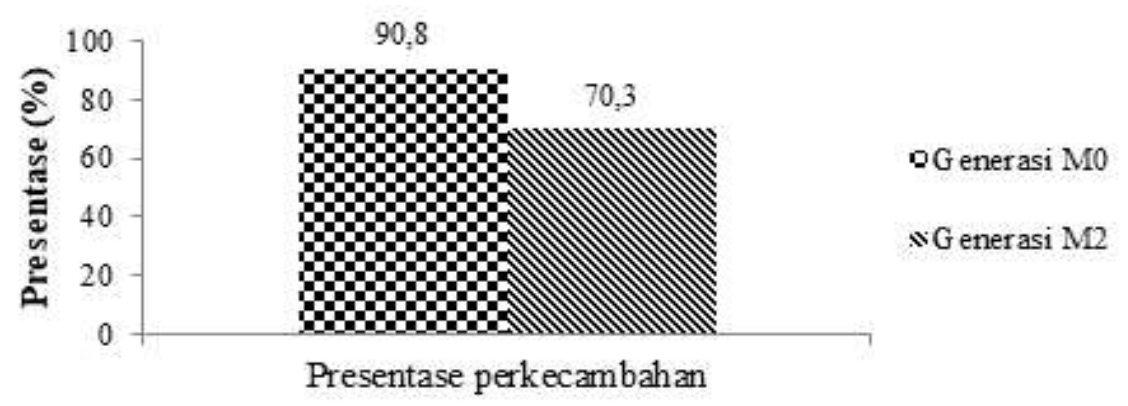

Gambar 1. Perbandingan presentase perkecambahan antara M2 dan M0 tanaman cabai varietas Laris hasil iradiasi sinar gamma

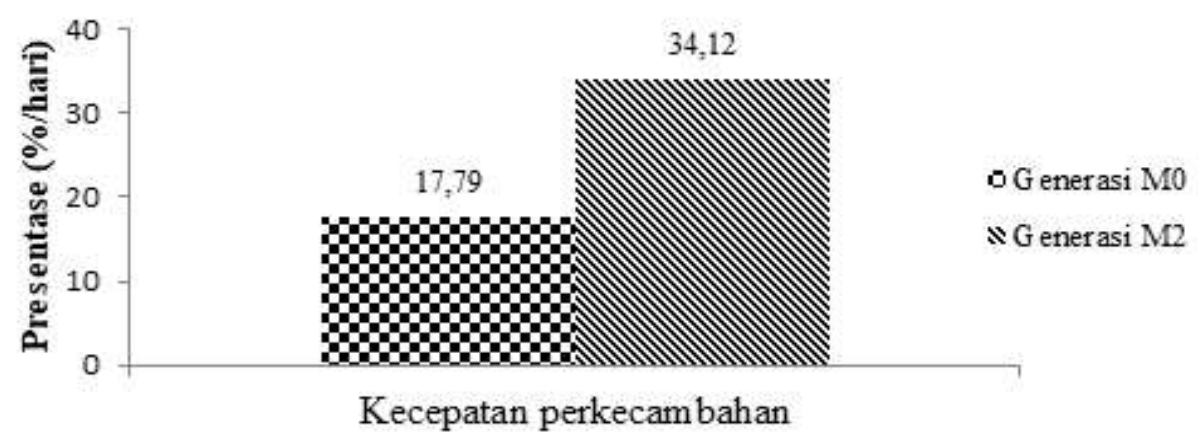

Gambar 2. Perbandingan kecepatan perkecambahan antara M2 dan M0 tanaman cabai varietas Laris hasil iradiasi sinar gamma

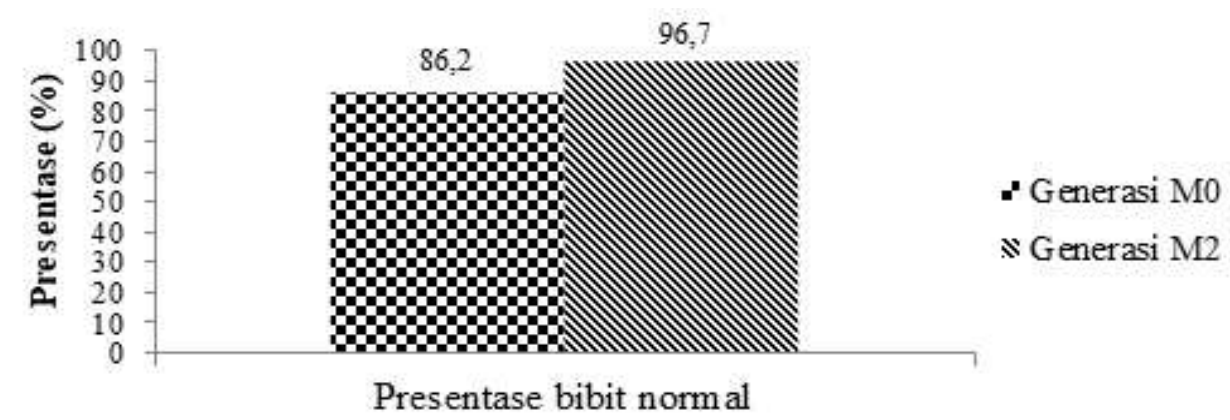

Gambar 3. Perbandingan presentase bibit normal antara M2 dan M0 tanaman cabai varietas Laris hasil iradiasi sinar gamma

M0 (Gambar 2 dan 3). Adanya peningkatan rata-rata pada karakter tersebut diduga sebagai wujud ekspresi positif dari gen-gen yang telah bermutasi. Melki M dan Morouni (2009) menyatakan hasil iradiasi sinar gamma pada tanaman gandum dapat meningkatkan kecepatan perkecambahan. Demikian pula pada penelitian Bassam (1996) menyatakan iradiasi sinar gamma dapat meningkatkan kecepatan perkecambahan.

Hasil penelitian menunjukkan bahwa populasi M2 tanaman cabai varietas Laris hasil iradiasi sinar gamma memiliki keragaman fenotipe yang luas untuk 


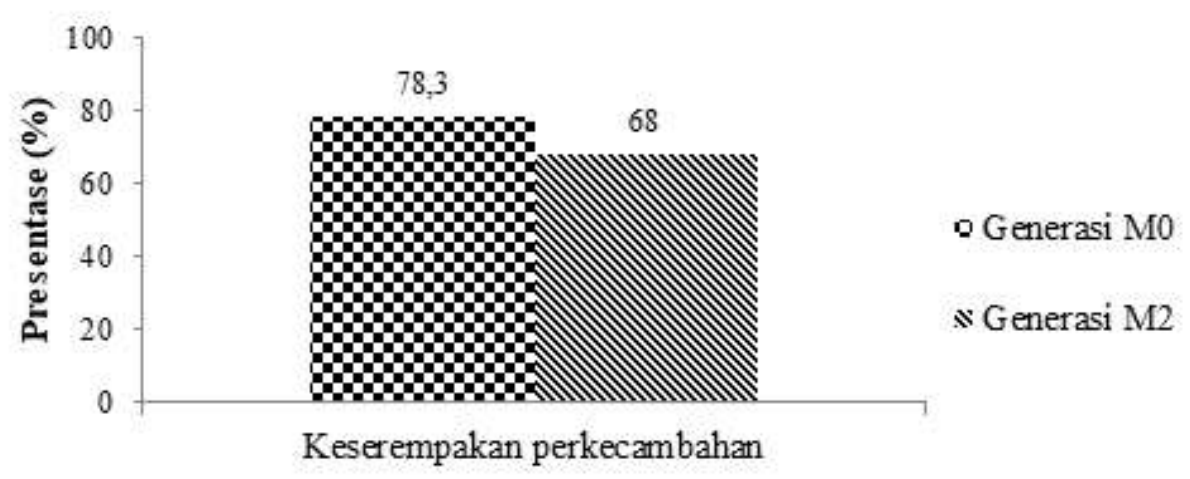

Gambar 4. Perbandingan keserempakan perkecambahan antara M2 dan M0 tanaman cabai varietas Laris hasil iradiasi sinar gamma

Tabel 1. Nilai ragam dan kriteria keragaman fenotipe dan genotipe populasi M2 cabai varietas Laris hasil iradiasi sinar gamma

\begin{tabular}{lcccccc}
\hline \multirow{2}{*}{ Karakter } & \multicolumn{3}{c}{ Fenotipe } & \multicolumn{3}{c}{ Genotipe } \\
\cline { 2 - 7 } & $\begin{array}{c}\text { Ragam } \\
\text { fenotipe }\left(\sigma_{f}^{2}\right)\end{array}$ & $2\left(\sigma_{f}\right)$ & Kriteria & $\begin{array}{c}\text { Ragam } \\
\text { genotipe }\left(\sigma_{g}^{2}\right)\end{array}$ & $2\left(\sigma_{g}\right)$ & Kriteria \\
\hline Tinggi bibit & 6,37 & 5,05 & Luas & 0 & 0 & Sempit \\
Tinggi tanaman saat berbunga & 15,97 & 7,99 & Luas & 2,71 & 3,30 & Sempit \\
Panjang cabang primer & 0,64 & 1,60 & Sempit & 0 & 0 & Sempit \\
Jumlah cabang primer & 0,02 & 0,29 & Sempit & 0,02 & 0,29 & Sempit \\
Diameter batang pada posisi 1 & 0,09 & 0,60 & Sempit & 0,06 & 0,47 & Sempit \\
cm di bawah cabang utama & & & & & &
\end{tabular}

Keterangan: Keragaman luas : $\left(\sigma_{g}^{2}\right)>2\left(\sigma_{g}\right)$; Keragaman sempit : $\left(\sigma_{g}^{2}\right)<2\left(\sigma_{g}\right)$

Keragaman luas : $\left(\sigma_{f}^{2}\right)>2\left(\sigma_{f}\right)$; Keragaman sempit : $\left(\sigma_{f}^{2}\right)<2\left(\sigma_{f}\right)$

parameter tinggi bibit dan tinggi tanaman saat berbunga

(Tabel 1). Hal ini sejalan dengan pendapat Purba dkk.

(2013) menyatakan hasil pengamatan tanaman kedelai untuk parameter tinggi tanaman memiliki keragaman fenotipe yang luas. Keragaman fenotipe sempit terdapat pada karakter panjang cabang primer, jumlah cabang primer dan diameter batang. Hal ini sejalan dengan pendapat Effendy dkk. (2017) menyatakan hasil pengamatan pada tanaman ciplukan (Physalis sp.) karakter jumlah cabang primer dan diameter batang memilki keragaman fenotipe rendah.
Pengamatan keragaman genetik populasi M2 menunjukan keragaman genetik yang sempit untuk karakter tinggi bibit, tinggi tanaman saat berbunga, jumlah cabang primer, panjang cabang primer dan diameter batang pada posisi $1 \mathrm{~cm}$ dibawah cabang utama (Tabel 1). Hasil ini sejalan dengan penelitian Syukur dkk. (2011), Septiyana (2015) dan Wulandari dkk. (2016). Syukur dkk. (2011) menyatakan pada pengamatan tanaman cabai karakter tinggi tanaman dan diameter batang memiliki keragaman genotipe yang sempit. Septiyana (2015) menyatakan pada penelitian 
Tabel 2. Heritabilitas arti luas popolasi M2 cabai varietas Laris hasil iradiasi sinar gamma

\begin{tabular}{lcc}
\hline \multicolumn{1}{c}{ Karakter } & $\mathrm{H}$ & Kriteria \\
\hline Tinggi bibit & 0 & Rendah \\
Tinggi tanaman saat berbunga & 0.17 & Rendah \\
Panjang cabang primer & 0 & Rendah \\
Jumlah cabang primer & 1.00 & Tinggi \\
Diameter batang pada posisi $1 \mathrm{~cm}$ di bawah cabang utama & 0.63 & Tinggi \\
\hline
\end{tabular}

Keterangan: Heritabilitas tinggi apabila $\mathrm{H}>0,5$; Heritabilitas sedang apabila $0,2 \leq \mathrm{H} \leq 0,5$; Heritabilitas rendah apabila $\mathrm{H}<0,2$ (Syukur dkk., 2011).

kacang panjang karakter tinggi tanaman dan jumlah cabang memliki keragaman genotipe yang sempit.

Nilai ragam genetik dan ragam fenotipe menentukan besarnya nilai heritabilitas. Pada penelitian ini untuk karakter tinggi bibit, tinggi dikotomus tanaman saat berbunga dan panjang cabang primer memiliki nilai heritabilitas yang rendah. Nilai duga heritabilitas yang rendah karena beberapa nilai heritabilitas nol. Nilai heritabilitas yang bernilai nol sebagai akibat keragaman genotipe yang bernilai nol (Maryenti dkk., 2015). Hal ini sejalan dengan penelitian Septiyana (2015) yang menyatakan bahwa pada tanaman kacang panjang karakter tinggi tanaman memiliki nilai heritabilitas yang rendah.

Heritabilitas yang tinggi terdapat pada karakter jumlah cabang primer dan diameter batang (Tabel 2). Hal ini sejalan dengan penelitian Hanafiah dkk. (2015) dan Kusuma dkk. (2016). Hanafiah dkk. (2015) menyatakan pada tanaman kedelai kondisi optimum, nilai duga heritabilitas arti luas yang tinggi ditemukan pada karakter jumlah cabang produktif dan bobot biji per tanaman pada masing-masing populasi iradiasi. Begitupun pada penelitian Kusuma dkk. (2016) menyatakan nilai duga heritabilitas yang tinggi pada karakter jumlah cabang. Nilai heritabilitas yang tinggi dari karakter yang diamati menunjukkan bahwa karakter tersebut lebih banyak dikendalikan oleh faktor genetik dari pada faktor lingkungan ( Suharsono dkk., 2006). Keadaan ini mengindikasikan bahwa seleksi dapat diterapkan pada karakter tersebut.

\section{KESIMPULAN}

Kesimpulan dari penelitian ini adalah keragaman fenotipe yang luas terdapat pada karakter tinggi bibit dan tinggi tanaman saat berbunga, sedangkan untuk keragaman genotipe semua karakter menunjukkan kriteria sempit. Besaran nilai heritabilitas yang tinggi ditunjukkan pada karakter jumlah cabang primer dan diameter batang pada posisi $1 \mathrm{~cm}$ dibawah cabang utama, sedangkan untuk karakter tinggi bibit, tinggi dikotomus tanaman saat berbunga, dan panjang cabang primer memiliki nilai heritabilitas yang rendah.

\section{DAFTAR PUSTAKA}

Badan Pusat Statistik. 2017. Statisitik Tanaman Sayuran dan Buah-Buahan Semusim. Jakarta. BPS Indonesia. 
Bassam. 1996. Effect of gamma rays and EMS on seed germination and plant survival of Pisum sativum L. Neo Botanica. 4 (1) : 25-29

Effendy., Respartijati., Waluyo, B. 2017. Keragaman genetik dan heritabiltas karakter komponen dan hasil ciplukan (Physalis sp.). Jurnal Agro. 5(1):30-38.

Hanafiah, D. S., Trikoesoemaningtyas, S. Yahya., dan D. Wirnas. 2015. Keragaan generasi ketiga (M3) kedelai hasil iradiasi sinar gamma pada kondisi optimum dan kondisicekaman kekeringan. Jurnal Pertanian Tropik. 2(1) : 21 - 28.

Ishak. 2012. Sifat agronomi, heritabilitas dan interaksi G x E galur mutan padi gogo (Oryza sativa L.). J. Agron Indonesia. 40 (1) : 105-111.

Kusuma, R., N. Sa'diyah., dan Y. Nurmiaty. 2016. Keragaman fenotipe dan heritabilitas kedelai (Glycine max L. Merril) generasi F6 hasil persilangan Wilis x MLG2521. Jurnal Penelitian Pertanian Terapan. 16(2) : 85 - 93.

Lestari, E.G., Purnamaningsih R., Asadi, Hutami S, dan Rahayu S.2015. Mutasi dan kultur invitro untuk meningkatkan keragaman genetik tanaman kedelai. Balai Besar Penelitian Bogor.

Maryenti, T., Bermwai, M., dan Prasetyo, J. 2015. Heritabilitas dan kemajuan genetik karakter ketahanan kedelai generasi F2 persilangan Tanggamus x B3570 terhadap soybean mosaic virus. Jurnal Kelitbangan. 2 (2).

Melki, M dan Marouni, A. 2009. Effect of gamma rays irradiration on seed germination and growth of hard wheat. Environ chem Lett. 8 : 307-310
Nurrachmamila, P.L dan Saputro, T.B. 2017. Analisis daya perkecambahan padi (Oryza sativa L.) varietas Bahbutong hasil iradiasi. Jurnal sains dan seni ITS. 6(2) : 2337-3520

Pinasthika., Florentina K., dan Syaiful A. 2018. Evaluasi karakter agronomi kedelai varietas Detam 3 Prida hasil mutasi iradiasi sinar gamma generasi M2. Agrista. 20 (3)

Purba, K. R., Bayu, E.S., dan Nuriadi, I. 2013. Induksi mutasi radiasi sinar gamma pada beberapa varietas kedelai hitam (Glycine max L. merril). Jurnal Online Agroteknologi. 1 (2) : 154 - 165.

Ratma R dan Riyanti S,. 1998. Pengaruh Iradiasi Sinar Gamma terhadap Mutasi Klorofil dan Variasi Genetdk SbfatAgronomi Pada Tanaman Kedelai. Pusat Aplikasi Isotop dan Radiasi. BATAN.

Septiyana. 2015. Pengaruh pemberian dan jenis-jenis pupuk kandang serta pupuk kimia terhadap pertumbuhan kacang panjang (Vigna sinensis L.). Skripsi. Universitas Islam Negeri Sunan Kalijaga. Yogyakarta.

Suharsono, Yusuf, M dan Paserang A.P. 2006. Analisis ragam, heritabilitas dan pendugaan kemajuan seleksi populasi F2 dari persilangan kedelai kultivar Slamet x Nokonsawon. Tanaman Tropika 9 (2): 86-93.

Syukur, M., Sujiprihati, S., Yunianti, R., dan Kusumah, D.A. 2011. Pendugaan ragam genetik dan heritabilitas karakter komponen hasil beberapa genotipe cabai. Jurnal Agrivigor. 10 (2) : 148-156.

Yunianti, R., Sastrosumarjo, S., Sujiprihati, S., Surahman, M., Hidayat, S.H. 2010. Kriteria seleksi untuk perakitan varietas cabai tahan Phytophthora capsici Leonian. J. Agron. Indonesia 38(2):122-129. 